\title{
Mitigation Technology In Ruminants To Reduce The Negative Impacts of Global Warming
}

\author{
Nining Haryuni \\ Universitas Nahdlatul Ulama Blitar \\ E-mail: niningharyuni@gmail.com
}

Received: 3 February 2018; Revised: 21 July 2018; Accepted: 25 July 2018

\begin{abstract}
Abstrack
The method used in writing this article is a review of several journals related to methane mitigation technology in ruminants. The purpose of writing this article is to know the technologies that can be applied to the field of animal husbandry to reduce the effects of methane produced by ruminants that can cause global warming. Methane is produced mostly from ruminants in feed fermentation process that occurs in the rumen. $80-95 \%$ is produced from fermented feed and $5-20 \%$ is produced in the colon. Methane emission mitigation measures in ruminant livestock are conducted in several ways including improving feed quality by increasing concentrate composition, adding feed additive to feed and utilization of acetogenic bacteria.
\end{abstract}

Key words: mitigation technology, methane, ruminants, global warming

\section{Introduction}

Global warming is a process of increasing the average temperature of the atmosphere, the ocean and the earth's land. For the last hundred years the average temperature on the earth's surface has increased by $0.74 \pm 0.18^{\circ} \mathrm{C}(1.33 \pm$ $0.32^{\circ} \mathrm{F}$ ). Increasing temperatures on the earth's surface may lead to disturbance of forests and other ecosystems that will have an impact on the declining ability of nature to absorb the gases that can cause the thinness of the ozone layer in the atmosphere. The Intergovernmental Panel on Climate Change (IPCC) states that this increase in average temperature is caused by increasing concentrations of greenhouse gases (Suarsana and Wahyuni, 2011). The negative impacts of the greenhouse effect are global warming that causes erratic climate change (Gustiar et al., 2014). Uncertain climate change is influenced by gas molecules contained in the troposphere layer that have an important role in maintaining the temperature of the earth's air to be stable contaminated by methane (Thalib, 2011). Other effects of global warming accord- ing to Suwedi (2005) are the melting of the polar ice sheet, sea level rise, the loss of small islands and the sinking of coastal islands, coral reef damage, coastal erosion, the emergence of EL Nino / ENSO natural phenomena, floods, drought, forest fires and outbreaks of disease. The effects of global warming make the world aware that there is a need to overcome it. one of them by reducing the activities that can cause negative impacts of greenhouses.

One contributor to greenhouse gas emissions is agriculture. Agriculture ranks fourth in donating greenhouse gases. Agricultural sectors that contribute to greenhouse gas emissions include livestock, rice cultivation, burning of savannah and burning of agricultural wastes. Livestock accounts for $24.1 \%$ of total greenhouse gas emissions coming from the agricultural sector (Gustiar et al., 2014). Greenhouse gas emissions from livestock are produced by ruminants. To reduce the negative impact of global warming caused by the emission of methane produced by ruminant livestock, it is necessary to study the technologies that can reduce the production 
of methane in ruminant livestock.

\section{Material and Methods}

The material used in writing this article is a collection of research journals on methane mitigation technology in ruminants. The method used in the writing is a review of the journals.

\section{Discussion}

\section{Negative Impacts of Methane}

Approximately $55 \%$ of solar energy in the form of eletromagnetic radiation that can directly reach the surface of the earth and utilized for the activities of living things on earth such as photosynthesis, water evaporation and others. At a further warming the surface of the earth will act as a radiator of energy that will reradiate electromagnetic radiation back into the atmosphere in the form of infrared rays (IR). IR rays that are emitted into the atmosphere by the surface of the earth will be absorbed by the gases in the atmosphere. The IR energy absorbed by these atmospheric gases is re-emitted to the earth's surface so that the surface temperature of the earth increases. The atmospheric gases that play a role in the process of re-emission of electromagnetic radiation energy back to earth are known as greenhouse gases (Haryanto and Thalib, 2009). In principle this greenhouse effect is needed by all the creatures that exist on the surface of the earth. Without the greenhouse effect, the earth will become very cold with temperatures at -18 oC initially which can cause the surface of the earth to be covered by the ice sheet. With an average temperature of $15^{\circ} \mathrm{C}\left(59^{\circ} \mathrm{F}\right)$, the earth has actually been warmer $33^{\circ} \mathrm{C}\left(59^{\circ}\right.$ F) than its original temperature. But on the contrary if the greenhouse gases have been excessive in the atmosphere, it will cause global warming. Based on the simulation calculations, the average temperature on the surface of the earth has increased by $1-5 \mathrm{oC}$ due to the greenhouse effect. It is estimated that by 2030 there will be an increase in global warming between 1.5-4.5 oC if the trend of increasing greenhouse gases remains the same (Suarsana and Wahyuni, 2011).

Increasing the concentration of greenhouse gases in the atmosphere can be caused by natural processes as a result of chemical activity in nature and due to human activities. The concentration of greenhouse gases has increased significantly compared to the pre-industrial era around $1750 \mathrm{~s}$. CO2 increase by $34 \%, \mathrm{CH} 4$ by $152 \%$ and $\mathrm{N} 2 \mathrm{O}$ by $18 \%$ (Haryanto and Thalib,
Table 1. National Greenhouse Gas Emissions (GHG) in Agricultural Sector (in million tons of $\mathrm{CO}_{2}$-eq) Year 2007

\begin{tabular}{|l|c|c|}
\hline $\begin{array}{l}\text { Source of } \\
\text { emissions }\end{array}$ & $\begin{array}{c}\mathrm{CO}_{2}-\mathrm{eq}^{*} \\
\text { (million tons) }\end{array}$ & $\begin{array}{c}\text { Composition } \\
(\%)\end{array}$ \\
\hline Rice / rice field & 53,84 & 60,8 \\
Livestock & 21,32 & 24,1 \\
Farmland & 3,27 & 3,7 \\
Organic mass burning & 10,1 & 11,4 \\
\hline Total & 88,53 & 100 \\
\hline
\end{tabular}

2009). According to Gustiar et al. (2014) the Ministry of Environment in 2010 has stated that sectorally the fourth largest emitter of greenhouse gas emissions is occupied by agriculture sectors derived from livestock, rice field cultivation, burning of savannah, burning agricultural waste and agricultural land. Total emissions of greenhouse gases from agriculture $24.1 \%$ obtained from livestock activities. National greenhouse gas emissions in the agricultural sector can be seen in Table 1.

\section{Methanogenesis}

Greenhouse gas emissions from livestock activities are methane $\left(\mathrm{CH}_{4}\right)$. Methane gas is produced mostly from ruminants during feed fermentation process in the rumen. $80-95 \%$ of methane is produced from fermented feed and 5$20 \%$ is produced in the colon. Methane produced in the rumen will be released into the atmosphere through the mouth of the livestock (Nur et al., 2015). Livestock that contribute to methane emissions can be seen in Figure 1.

The organic compounds of feed ingredients in the rumen will be fermented by rumen microbes. Rumen microbes that play a role in the methanogenesis process include Methanobrevibacter, Methanobacterium formicicum, Methanobrevibacter ruminantium, Methanosaricina bark-

Figure 1. Type of Livestock Contribution of Methane Emission. (Source: Thalib, 2011)

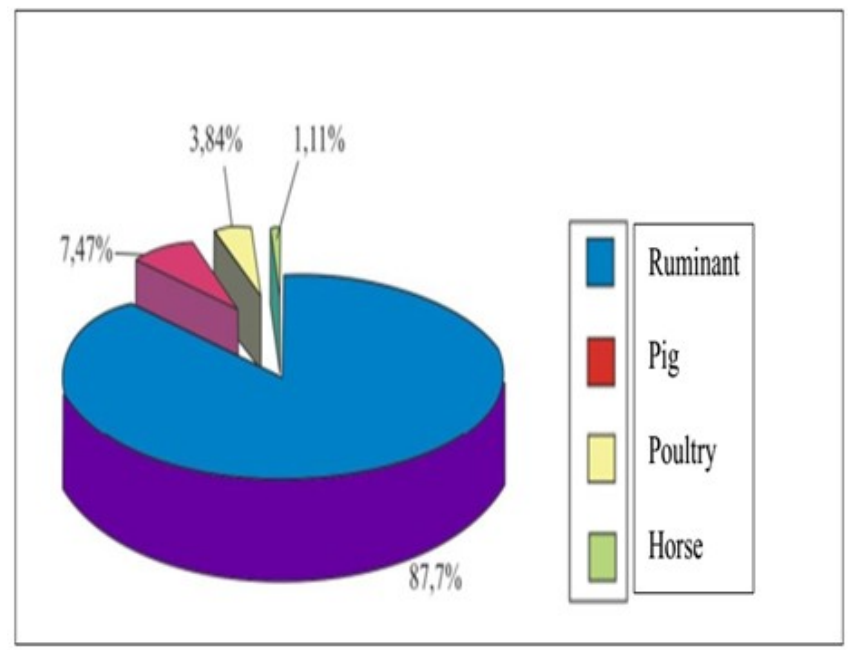




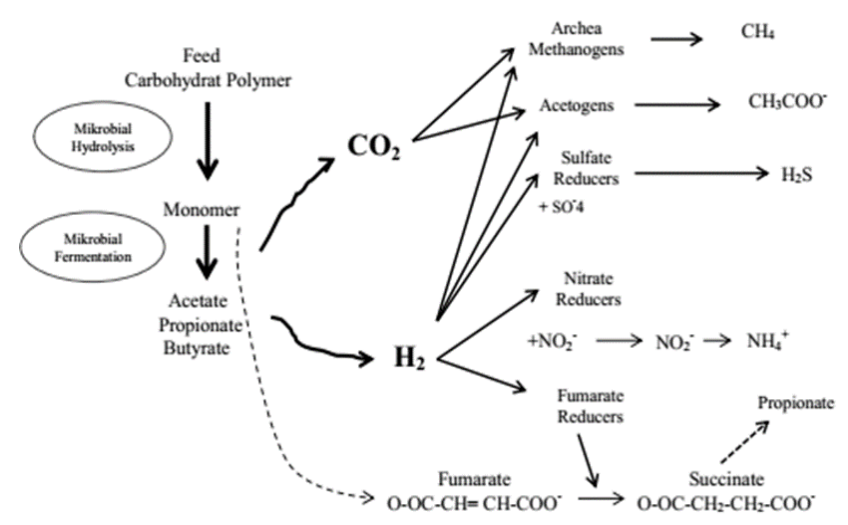

Figure 2. Production of Methane in Ruminant Livestock (Source: Karri et al., 2015)

eri, Methanosaricina mazei, Methanomicrobium mobile and others (Karri et al., 2015). The results of this rumen microbial fermentation are volatile fatty acids (VFA), CO2, $\mathrm{H} 2$ and ammonia (NH3). The methanogenesis by methanogen is caused by $\mathrm{CO} 2$ reduced by $\mathrm{H} 2$ to form $\mathrm{CH} 4$ (methane). Approximately $83 \%$ of methane is released by the body of cattle through eructation, $16 \%$ through respiration and 1\% through feces (Thalib et al., 2010). In general, feed with high fiber content will produce acetic acid and methane higher than concentrate feeds derived from grains (Nur et al., 2015). Methane produced by ruminants reflects a large amount of energy loss and indicates a low feeding efficiency (Widiawati et al., 2010). In the process of methanogenesis the lost energy used to produce methane can reach $15 \%$ of the total digested energy (Thalib et al, 2010). Production of methane in ruminants can be seen in Figure 2.

Methane emissions produced by ruminant livestock are influenced by many factors such as livestock type, organic matter content in feed, fiber content in feed, fiber degradability value in rumen and rumen environmental conditions (Haryanto and Thalib, 2009). Methane emissions in the world can be seen in Figure 3.

Figure 3. Methane Emissions in the World (Source: Haryanto and Thalib, 2009)

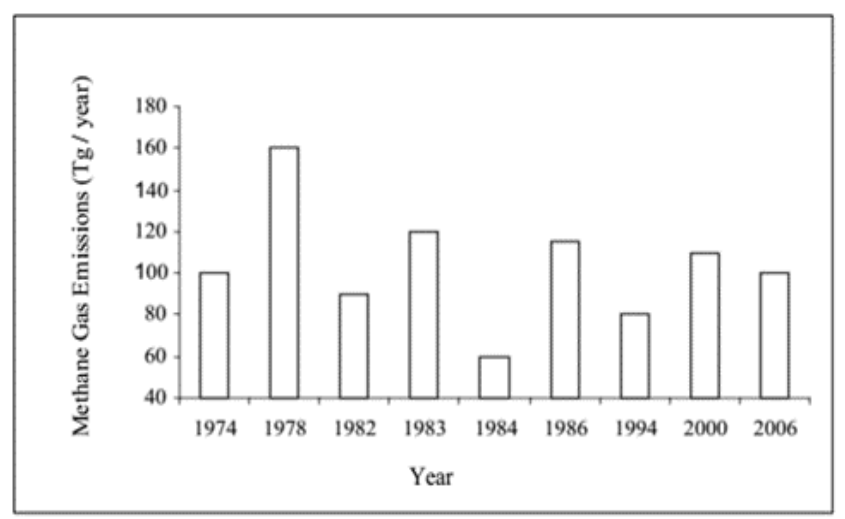

\section{Methane Emission Mitigation in Ruminant Livestock}

The approaches to mitigate methane emissions are:

1. Improved feed quality by increasing concentrate composition. Gustiar et al. (2014) reported that the addition of concentrate to feed can decrease the methane production resulting from the fermentation process in the rumen.

2. Use of feed additives on the feed. The principle of using feed additives using various types of chemicals is inhibiting the activity of methanogenic microorganisms based on the toxicity of methanogenic microorganisms (Bamualim et al., 2008). Various types of feed additives have been reported to inhibit methanogenesis effectively with several types of mechanisms, including methane derivates, long-chain unsaturated fatty acids, ferric ions and sulfuric ions and saponin compounds (Thalib, 2011). The use of ferric ion $(\mathrm{Fe} 3+)$ as feed additive can decrease methane production from ruminant gastrointestinal by $22 \%$, SO42-ion use in feed can decrease methane concentration by $10 \%$ and use of unsaturated long-chain fatty acid in feed can decrease methane concentration by $11 \%$. The use of lerak extract with $15 \%$ saponin content in feed can decrease methane production by $31 \%$ while milled lerak material (not extracted) can decrease methane concentration in gastrointestinal by $21 \%$. (Suharti et al., 2011., Haryanto and Thalib, 2009).

3. Utilization of acetogenic bacteria The acetogenic bacteria can be utilized to decrease the production of methane in the gastrointestinal tract of ruminants. This bacterium is isolated from rumen fluid by using carbon monoxide (CO) acetone media and a medium which can utilize $\mathrm{CO} 2$ and $\mathrm{H} 2$. Utilization of acetogenic bacteria in ruminants can decrease methan concentration by $11-27 \%$ (Haryanto and Thalib, 2009).

\section{Conclusion}

The conclusions obtained from the writing of this paper are the production of methane in ruminant livestock is due to inefficient use of feed that can have a negative impact on the environment that can cause greenhouse effect. Methane emission mitigation in ruminant livestock among others by using several approaches such 
as improving feed quality, adding feed additive to feed and utilization of acetogenic bacteria.

\section{References}

Bamualim, A. M., A. Thalib., Y.N. Anggraeni and Mariyono. 2008. Teknologi Peternakan Sapi potong Berwawasan Lingkungan. Jurnal Wartazoa Vol.18 No.3: 149-156.

Gustiar. F., R.A.Suwignyo., Suheryanto and Munandar. 2014. Reduksi Gas Metan (CH4) dengan Meningkatan Komposisi Konsentrat dalam

Pakan Ternak Sapi. Jurnal Peternakan Sriwijaya Vol. 3 No. 1:14-24.

Haryanto, B and A. Thalib. 2009. Emisi Metana Dari Fermentasi Enterik: Kontribusinya

Secara Nasional Dan Faktor-Faktor Yang

Mempengaruhinya Pada Ternak. Jurnal Wartazoa Vol. 19 No. 4: 157-165.

Karri. S., S.G. Talla and Sirohi.S.K. 2015. An Overview Of The Role Of Rumen Methanogens In Methane Emission And Its Reduction Strategies. Academic Journals Vol.14 No.16: 1427-1438.

Nur. K., A. Atabani., Muladno and A. Jayanegara. 2015. Produksi Gas Metan Ruminansia Sapi Perah dengan Pakan Berbeda serta Pengaruhnya terhadap Produksi dan Kualitas Susu. Jurnal Ilmu Produksi dan Teknologi Hasil Peternakan Vol. 03 No. $2: 65-71$.

Suharti, S., D.A. Astuti, E. Wina and T. Toharmat. Rumen Microbial Population in the In vitro Fermentation of Different Ratios of Forage and Concentrate in the Presence of Whole Lerak (Sapindus rarak) Fruit Extract Asian-Australian Journals Animal Science Vol. 24, No. $8: 1086-1091$

Suarsana. M and P. S. Wahyuni. 2011. Global Warming: Ancaman Nyata Sektor Pertanian

Dan Upaya Mengatasi Kadar Co2 Atmosfer. Widyatech Jurnal Sains dan Teknologi Vol. 11 No. $1: 31-46$.

Suwedi. N. 2005. Upaya Pencegahan Dan Penanggulangan Dampak Pemanasan Global.

Jurnal Teknologi Lingkungan P3TL-BPPT Vol 6. No.2: 397-401.

Thalib, A and Y. Widiawati. 2008. Efek Pemberian Bakteri Acetoanaerobium noterae terhadap Performans dan Produksi Gas Metana pada Ternak Domba. Jurnal Ilmu Ternak Veteriner Vol. 13 No.4 : 273-278.
Thalib, A., Y. Widiawati and B. Haryanto. 2015. Penggunaan Complete Rumen Modifie (CRM) pada Ternak Domba yang Diberi Hijauan Pakan Berserat Tinggi. Academic Journlas Vol. 14 No. 16 : 1427-1438.

Thalib. A. 2011. Perkembangan Teknologi Peternakan Terkait Perubahan Iklim: Teknologi Mitigasi Gas Metan Enterik Pada Ternak Ruminansia. Seminar dan Lokakarya Nasional Kerbau 2011.

Widiawati. Y., M.Winugroho and P. Mahyuddin. Estimasi Produksi Gas Metana Dari Rumput Dan Tanaman Leguminosa Yang Diukur Secara In Vitro. Seminar Nasional Teknologi Peternakan dan Veteriner 2010. 